\title{
Respect for Planning Tools and Disparities in the Access of Populations to Basic Social Services in the Circle of Koutiala
}

\author{
Abdoulaye Sanogo \\ Management Science, Institute of University Pedagogy (IPU), Bamako, Mali \\ Email: sanogo.abdoulaye@yahoo.fr
}

How to cite this paper: Sanogo, A. (2021) Respect for Planning Tools and Disparities in the Access of Populations to Basic Social Services in the Circle of Koutiala. Technology and Investment, 12, 1-15. https://doi.org/10.4236/ti.2021.121001

Received: December 20, 2020

Accepted: February 2, 2021

Published: February 5, 2021

Copyright $\odot 2021$ by author(s) and Scientific Research Publishing Inc. This work is licensed under the Creative Commons Attribution International License (CC BY 4.0).

http://creativecommons.org/licenses/by/4.0/

\section{(c) (i) Open Access}

\begin{abstract}
After a short reminder of the types of planning tools that exist in the Circle of Koutiala, this article presents the situation on the consistency of planning tools. Then, it makes the link between respect for planning tools and the disparity in access of populations to basic social services (health, education, water, electricity, etc.). Non-compliance with the guidelines of planning tools is measured through the population's access to basic social services (health, education, water, electricity, etc.) in 10 municipalities in the Circle. After analysis, it turned out that, in the Circle of Koutiala as elsewhere in Mali, planning specifically faced several weaknesses. As such, we can note that the growing gap between the plans and the real economic decision-making process of communities, and even of the State, making planning tools mere documents left in drawers. As a result, the objectives set were rarely achieved at the level of economic and even social expectations. This article also presents the inter and intra communal disparity that exists in the Circle of Koutiala where one thing is to salute the efforts made by the State and the Communities to improve the living environment of the populations of the city of Koutiala and another one is to deplore the timid construction of infrastructure/equipment in the other towns of the Circle.
\end{abstract}

\section{Keywords}

Consistency of Planning Tools, Territorial Balance, Equitable Distribution of Investments, Balanced and Sustainable Development, Access to Basic Social Services

\section{Introduction}

It is one thing to have the planning tools; it is another thing to ensure that the 
guidelines of these tools are respected in order to promote equitable access for all citizens to basic social services at any time and in any place.

This access cannot be done if there is room for trial and error. It is well aware of this state of affairs that the Circle of Koutiala has equipped itself with several planning and development planning tools.

The first reference planning tool at the Circle level is the Local Land Use Planning Scheme (SLAT), a reference tool for spatial planning, but which has not been revised and evaluation since its adoption in 2002 (Koutiala Circle Council, 2002). This tool is operationalized by Economic, Social and Cultural Development Programs (PDESC).

Failure to respect the guidelines of planning tools can have a negative impact on the populations' equitable access to basic social services. This leads us to ask the question about the impact of non-compliance with the guidelines of planning tools on equitable access by populations to basic social services, a factor in the sustainable and balanced development of any territory.

The objectives of this article are to:

- Check the consistency of existing planning tools;

- Verify the distribution of socio-economic infrastructure and equipment on the territory of the Circle of Koutiala;

- Verify the equitable access of the populations to basic social services.

The Circle of Koutiala, located in the region of Sikasso, the third administrative region of Mali, is bordered to the north by the Circle of San, to the northwest by the Circle of Bla, to the southwest by the Circle of Dioila, to the south by the Circle of Sikasso and the Republic of Burkina Faso and in the East by the Circle of Yorosso. It covers an area of $8740 \mathrm{~km}^{2}$ or $12.17 \%$ of the total area of the Region and $0.7 \%$ of that of Mali. The Circle of Koutiala is made up of 35 rural Municipalities and one urban Municipality for a total of 262 villages/hamlets (Koutiala Communal Councils, 2017-2018). In 2009, the population of the Circle of Koutiala was estimated at nearly 580,453 inhabitants (National Institute of Statistics-INSTAT, 2009).

In 2018, it rose to 775,861 inhabitants with a density of 90.6 inhabitants per $\mathrm{km}^{2}$ (National Population Directorate 2018 Demographic Projection). The population is made up of Minianka, Bambara, Sénoufo, Peulh, Dafing, Dogon, Bwa, Mossi, Samogo, etc. (Koutiala Communal Councils, 2017-2018).

\section{Materials and Methods}

It consisted of a documentary search. The documents consulted are, national documents (the report of the Ségou workshop on the renewal of Planning in 1996, the five-year plans from 1961 to 1991, National Policies (transversal or sectoral), CREDD documents, etc.), reports and other sectoral documents, dissertations and theses.

Following this documentary research, we carried out a data collection initiated after sampling. The collection concerned 10 municipalities (The collection con- 
cerned 10 municipalities (Koutiala, Sincina, M'pèssoba, Fagui, Zangasso, N'Goutjina, Koningué, Nafanga, Kapala, Sinkolo) and 200 people (Bamako, Sikasso, Kati) and 200 people.

Of the 200 people to be surveyed in the municipalities, 98 people or $49 \%$ completed the questionnaire completely, 50 people or $25 \%$ partially completed the questionnaire by answering certain questions with a "nothing to report" and 52 people or $26 \% \mathrm{n}$ 'did not give any answers, anything that they motivated by ignorance of the subject and despite our attempts to explain, they preferred to direct us towards the Mayors, the Secretaries General, the notabilities, the leaders of the youth organizations and of women.

Among the municipal authorities (Mayors, Secretaries General) interviewed, around ten people were targeted and all answered our questions.

Interviews were also conducted with other actors responsible for implementing planning tools (NGOs, Private Sector, etc.).

It should be noted that the other municipalities were concerned by this collection through a documentary review.

Finally, it should be remembered that the interview guide was administered to specialists and resource persons (21 people from Bamako, Sikasso and Koutiala). An observation grid made it possible to observe physical achievements or other phenomena in certain villages in the targeted municipalities.

During this collection, we used three tools. It's about:

- The questionnaire;

- The interview guides;

- The observation grid.

Among the populations surveyed, there are 15 women of different ages (15 years and over) or $7.5 \%$ and 185 men of different ages (15 years and over) or $82.5 \%$.

The entry was made with Microsoft Word. As for the tables and graphs, they were drawn up with Microsoft Excel. Finally, SPSS was used to do some analyzes.

First of all, we looked at the consistency of planning tools at the level of the Circle of Koutiala.

\section{The Results}

They relate to the consistency of planning tools, their respect and the disparities in access to basic social services.

\subsection{Consistency of the Planning Tools of the Circle of Koutiala}

The first planning tool in the Circle remains the Local Land Use Planning Scheme. All the other tools must allow the spatial translation of its orientations.

Should it be emphasized, the first PDESC developed after SLAT in 2003 drew heavily on said SLAT unlike other planning tools that followed (Koutiala Circle Council, 2002).

Regarding the Master Plan for Development and Town Planning of the city of 
Koutiala and its surroundings, it is not inspired by the SLAT either. The second economic, social and cultural development program (2011-2015) is not part of the SLAT. It does not mention the results of the first PDESC which was not assessed.

This is why we will limit ourselves to the results of our observations, findings and analyzes to comment on compliance with economic development programs in the Circle by focusing on geographic and sectoral disparities. However, this program has not been evaluated, which is why it is difficult to say whether it is adhered to.

\subsection{Respect for Planning Tools}

When it comes to SLAT, it is difficult to say whether it has followed its guidelines, since it has never been evaluated. So, we decided to analyze the tools for implementing this scheme. This is the Master Plan for Development and Town Planning (SDAU), which was the subject of an evaluation in 2018. This evaluation made it possible to express an opinion on its degree of respect by the various actors through a report called the evaluation report of the implementation of the Master Plan of Development and Urbanism of the city of Koutiala and surroundings. From this report, it emerges that the SDAU for the city of Koutiala and its surroundings was revised in 2002 to be implemented over a period of twenty (20) years (deadline 2021). The availability of space in the city is hampered by illicit occupations. Most of the areas provided for in the plan are occupied according to illegal attributions of the Town Hall and customary authorities. This favored the change of vocation observed here and there (National Technical Assessment Committee of Urban Master Plans and Sectorial Town Planning Plans-CNET-SDU/PUS, 2018).

After nearly a decade of implementation, the overall achievement rate is $58.53 \%$ for scheduled equipment, $18 \%$ for roads, and $40 \%$ for sanitation and the environment (National Technical Assessment Committee of Urban Master Plans and Sectorial Town Planning Plans-CNET-SDU/PUS, 2018).

Regarding the PDESCs, it is difficult to say whether they are respected as they have not been evaluated and monitored as they should.

However, we will analyze the disparities in access which will make it possible to observe the respect of the orientations of the planning tools in terms of access to basic social services.

\subsection{Disparities in Population Access to Basic Social Services}

The coverage of the territories of the municipalities in infrastructure and basic social equipment is analyzed to highlight the disparities between inter and intra municipal.

\subsubsection{Access to Health}

In the Circle of Koutiala, according to the Regional Directorate of Health (DRS) of Sikasso in 2018, the number of Community health centers (CSCOMs) is estimated at 43 , of which only 10 are run by doctors (Table 1 ). 
Referring to Table 1, we see that the coverage in terms of infrastructure is acceptable, most municipalities have CSCOMs.

However, what should be emphasized is that the quality of services is not there, there are only 10 doctors for the 43 CSCOMs.

In the Circle, the number of new CSCOMs has not changed for 5 years.

The mobilization of resources for this strategic objective is insufficient, even non-existent, whereas the district needs new constructions in two Municipalities.

The number of CSCOMs held by a Doctor is 10 against 15 in the 2017 forecast. The objectives relating to the accreditation of CSCOMs have been very ambitious (out of 10 planned, 0 achieved), (Koutiala Communal Councils, 2017-2018).

Several villages are not located within a radius of $5 \mathrm{~km}$ from a CSCOM.

The degrading state of the roads, especially during the rainy season, makes it difficult for populations to access health centers, not to mention the lack of adequate means of transport. Only a few CSCOMs have ambulances (tricycle).

In the target municipalities, apart from the administrative centers of municipalities, the urban municipality of Koutiala, it appears that all the villages have difficulty accessing health centers, which is why the municipal authorities register each year the realization of health infrastructure and equipment in investment plans.

For example, in the Municipality of Fagui, the health infrastructures are poorly distributed. Only the village of Ziéna, capital of the town, houses a CSCOM which is more than $15 \mathrm{~km}$ from some villages. There are 03 maternities in the villages of Ziéna, Kèlèni and Bougoro.

The rural Municipality of Fagui, with a population of 13,823 , expresses a need for the creation and construction of a new CSCOM (Koutiala Communal Councils, 2017-2018).

Like the Municipality of Fagui, health infrastructure is poorly distributed in the municipalities. So we have:

Table 1. Circle health infrastructures in 2018.

\begin{tabular}{cccc}
\hline \multirow{2}{*}{ Circle/Distric } & \multicolumn{3}{c}{ Infrastructure/equipment } \\
\cline { 2 - 4 } & Koutiala & Total Region 2018 & 2017 Total Recall \\
\hline Referral health center (CSRéf) & 1 & 10 & 10 \\
Total CSCom Functional & 43 & 245 & 238 \\
CSCOM medicalized & 10 & 60 & 51 \\
Doctor's office & 7 & 63 & 55 \\
Medical clinic & 2 & 16 & 23 \\
Officine/pharmacy & 17 & 67 & 69 \\
Confessional Hospital & 1 & 1 & 1 \\
2nd referral hospital & 0 & 463 & 448 \\
Total & 81 & & 1 \\
\hline
\end{tabular}

Source: Regional Directorate of Health 2019. 
- Four (04) CSCOM for 194,438 inhabitants in the urban Municipality of Koutiala without counting that this Municipality is the capital of Cercle therefore it housed the only reference health center of the Cercle, a confessional hospital and several private practices and clinics (Koutiala Communal Councils, 2017-2018);

- One (01) CSCOM for 15,674 inhabitants in Sinkolo and with villages located more than $15 \mathrm{~km}$ away. It has six (06) maternity hospitals in the villages of Sinkolo, Blendo, Cissoumana, Kokosso, Tonondjombougou and Djélé (Koutiala Communal Councils, 2017-2018);

- One (01) CSCOM for 24,713 inhabitants in N'goutjina with three (03) maternity hospitals in the villages of N'goutjina, Bèlèsso and Finkoloni (Koutiala Communal Councils, 2017-2018);

- Three (03) CSCOM for 26,800 inhabitants in the villages of Zangasso, N'Tosso and Djitamana, three (03) maternity hospitals respectively in the villages of Sangaba, Tjarakassedougou and Fienso. These CSCOMs were created before the advent of the Municipalities and have qualified but insufficient staff (Koutiala Communal Councils, 2017-2018). It should be noted that the Municipality of Zangasso is better covered in terms of school and health infrastructure. Unlike these neighbors, it has three (03) CSCOMs and 10 schools;

- Two (02) CSCOM for 22,155 inhabitants in Sougoumba coming under the health district of Yorosso.

In this municipality, there are three (03) maternities respectively in the villages of Banesso, Dougan and N'guéguésso I (Koutiala Communal Councils, 2017-2018);

- One (01) CSCOM for 48,568 inhabitants in M'pèssoba and five (05) maternity units in the villages of Kintiéri, Pala, Nankorola, Bana, Dintiola (Koutiala Communal Councils, 2017-2018).

The villages of Gouantiésso, Sobala, Boudibougou, Kèmèssorola, N’Tarla, Kolomousso, and M'pessoba-Ferme do not fall within the M'pèssoba health area;

- One (01) CSCOM for 12,089 inhabitants, located in Karangasso with three (03) maternity hospitals in the villages of Kani, Zeguesso, Nintabougoro. This health center is not on behalf of the Municipality of the Municipality of Nafanga (Koutiala Communal Councils, 2017-2018). The health staff of the CSCOM is made up of a doctor, a health technician, an obstetrician nurse, a nurse's aide, a matron, a pharmacy manager. To this, we must add three matrons who manage the maternities. Support for the salaries of health personnel is provided by ASACO and the Diocese;

- One (01) CSCOM for 26,182 inhabitants located in Sincina with three (03) maternities in the villages of Sincina, Kaniko, Namposela (Koutiala Communal Councils, 2017-2018);

- The municipality of Kapala does not have a CSCOM, it has a rural maternity hospital in Sadiola for 11,400 inhabitants. Said Municipality uses the services of the CSCOMs of neighboring municipalities. These are the CSCOMs of N'goutjina, Molobala and Sinkolo (Koutiala Communal Councils, 2017-2018). 


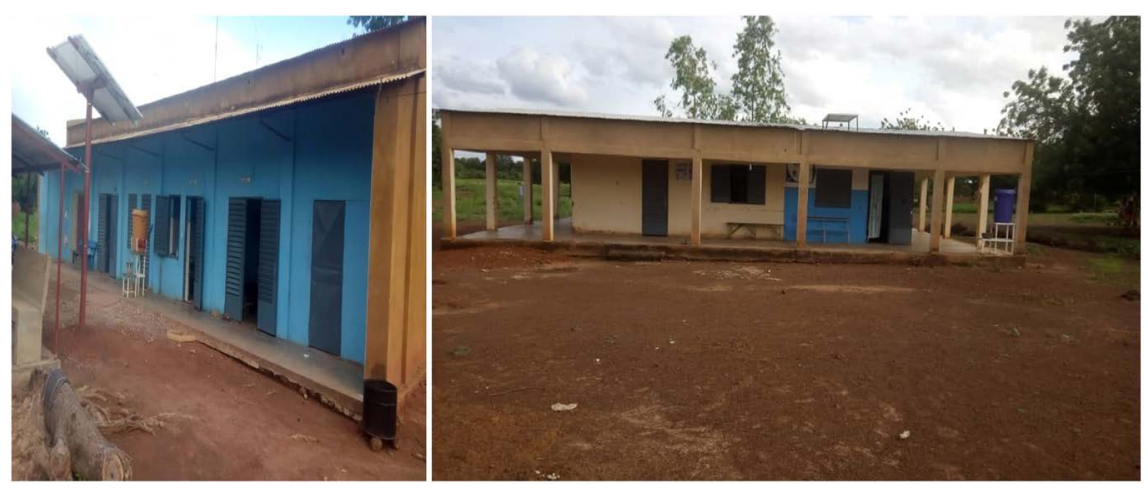

Source: personal photo April 28, 2019 at 10:30 a.m.

Photo 1. CSCOM Municipalities of Zangasso and Fagui.

These (Photo 1) illustrate the cramped state of the premises of the CSCOMs of the Municipalities of Zangasso and Fagui.

The said CSCOMs are also under-equipped and lack personnel in quantity and quality to meet the pressing demand of the populations of these Municipalities who are often obliged to join the town of Koutiala for treatment.

The condition of the roads and the lack of adequate transport make medical evacuations difficult in some villages where carts and motorcycles are still available for evacuation of complicated cases. Hence the need to provide these CSCOMs with adequate resources.

Lack of personnel, equipment and infrastructure are the major concerns to be highlighted in this sector and remains a major concern in all municipalities.

\subsubsection{Access to Education}

Regarding access to school, it is very difficult for some villages where there are no schools and where they exist, children face the double division linked to the lack of rooms of classes or teachers. In 2018, the Municipality of Koutiala had (Koutiala Communal Councils, 2017-2018):

- 1 st cycle level of basic education: 42 public schools, 27 private schools, 02 denominational schools, one community school and one CPD, i.e. 74 schools in total;

- 2nd cycle level of basic education: 26 public schools, 14 private schools, 01 community school, 02 denominational schools or 43 schools in total;

- Medersas: 35 schools in total;

- Kindergarten: 06 public and 02 denominational.

Overall, there is an average of 70.58 students per class for 58.28 students per teacher (Koutiala Communal Councils, 2017-2018).

For example, the Municipality of Fagui had in 2018, an enrollment of 1374 students for 37 classrooms including 06 in semi hard and 10 in mud for 09 schools including a second cycle in Ziéna. The total teaching staff was 38, of which 03 were women. In this Municipality the average number of pupils per class is 37 pupils.

With regard to the Municipality of Sinkolo, in 2018 it had an enrollment of 
1229 students for 32 classrooms including 06 in semi-hard and 07 in mud for 09 schools including a second cycle and a kindergarten in Sinkolo. The total teaching staff was 33 of which 09 were women. 10/33 teachers are on the national budget. The number of students per classroom is 38 students per class.

For the Municipality of N'goutjina, in 2018 there were an enrollment of 4474 students for 53 classrooms including 14 in semi-hard and 10 schools including two second cycle in N'goutjina and Wèlenguana and a kindergarten in N'goutjina.

The total teaching staff was 81 of which 21 were women. The rural Municipality of N'goutjina has an average of 84 students per classroom, or one teacher for 84 students.

For the Municipality of Koningué, there are 11 schools (03 second cycle and eight 1st cycles) located in Sougoumba, Banesso, N'gueguesso II and Dougan (Koutiala Communal Councils, 2017-2018).

The Municipality of Zangasso has ten (10) basic schools in the villages of Zangasso, N’Tosso, Djitamana, Fienso, Kolonto, Gare, Kiko, Tjarakassébougou, Sangaba and Kouguè.

Referring to the data collected in the field in the Municipality of M'pèssoba, it should be noted that the school enrollment rate was $68.82 \%$ (school year 2017-2018).

This illustrates the paths covered and the efforts to be made in terms of building classrooms and recruiting teachers.

The pupil/master ratio was 62.78 in the $1^{\text {st }}$ cycle for the desired average of 50 highs/master. The pupil/classroom rate is also above the average of 50 students per classroom.

At the second cycle level, the ratios do not reflect reality because some schools have needs in classrooms and teachers.

Despite this rate of schooling in the municipality, some villages remain without schools.

Most of the school infrastructure is concentrated at the level of the Municipality capital (M'pèssoba), which sufficiently proves that the territorial coverage is not balanced and entire villages, even large hamlets, do not have access at school.

The Municipality of Nafanga has 2071 students for 31 classrooms including 08 schools including a second cycle, a Catholic school in Karangasso (capital of the municipality). It should also be noted that there is a community school in Zeguesso, all of which are built in solid form.

The Municipality of Nafanga has an unequipped kindergarten in Nintabougoro. The total teaching staff is 39, of which 15 are women. The average number of students per class is 68 students (school year 2017-2018) in this municipality where the urgent need (according to the municipal authorities) is the creation of 15 rooms, not to mention the support of the next students.

As regards the Rural Municipality of Sincina, in 2018 it had: 08 public schools 1st Cycle of basic education (04 in the capital of the municipality), 05 public schools 2 nd Cycle of basic education (03 located in the capital of the municipal- 
ity), four (04) literacy centers, one (01) CED (Koutiala Communal Councils, 2017-2018).

Lack of library, shortage of staff and classrooms are urgent needs to be addressed in this sector.

As for the Municipality of Kapala, it has 7 schools ( 5 schools at the first cycle level and 2 schools at the second cycle level in Kapala and Chikoloba).

These (Photo 2) illustrate the quality of the infrastructures of these two Municipalities contrary to the Municipality of Fagui, these two Municipalities have well-housed basic schools even if the tree must not hide the forest, here too the demand is far from being satisfied in terms of classrooms and staff.

Territorial coverage in terms of access also leaves much to be desired in these municipalities where children continue to suffer from being far from schools.

All the municipalities are confronted in the field of education with the problems of equipment and qualified personnel.

The construction of classrooms, latrines, the creation of drinking water points and the recruitment of teachers are the actions that the town hall must face to meet the needs of education in the above-mentioned municipalities.

\subsubsection{Access to Drinking Water}

In terms of access to drinking water, the findings are far from satisfactory. Thus, many villages and hamlets are experiencing a lack of hydraulic works. The scarcity of water often causes problems of temporary or permanent clogging of water points, especially in areas where the water table is very low and in pastoral areas where water points are rare. It is during these periods that the water problem is really acute, both for food for men and for their agro-sylvo-pastoral activities.

Access to water is often made difficult by the non-functionality of hydraulic equipment.

In the urban municipality of Koutiala, only the town of Koutiala is partially supplied by the SOMAGEP water supply network, the installations of which must be extended to unserved areas.

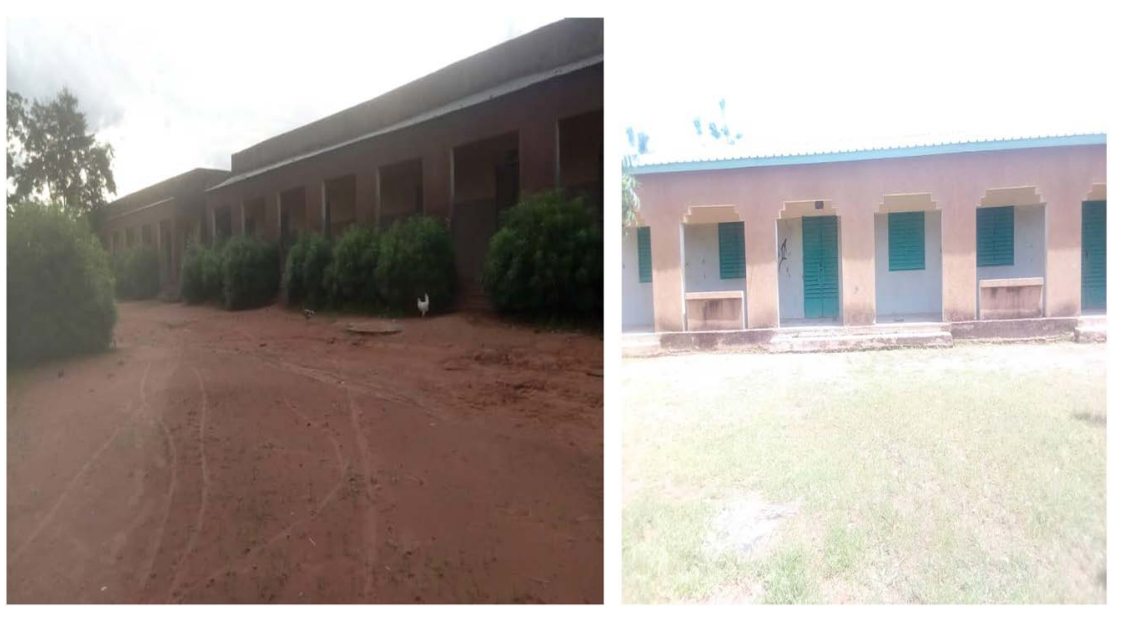

Source: personal photo April 30, 2019 at 11:20 a.m.

Photo 2. Basic school of the municipalities of Zangasso and Mièna. 
Regarding the supply of drinking water to the villages of this Municipality, it is provided by boreholes, large-diameter wells and others. In other words, the access of villages to drinking water must be improved.

For the Municipality of Fagui, the least we can say is that part of the population has so far obtained its supplies from traditional wells. For a population of 13,823 inhabitants, there are 12 boreholes, one of which is in poor condition, that of Gouembougou and two summary water supplies. If the number of inhabitants around a borehole must be 400 inhabitants, according to the standards, that of the rural Municipality of Fagui is far greater with a population of more than 1000 inhabitants for a borehole. This explains the need for 22 boreholes in the municipality where it is urgent to carry out additional boreholes to definitively solve the drinking water problem.

The Municipality of Sinkolo gets its supplies from traditional wells. The said Municipality has 17 boreholes, 03 of which are in poor condition (Blendo, Gouantéré and Djélé) plus a summary water supply in poor condition at Sinkolo for a total population of 15,674 inhabitants, or more than 900 inhabitants for a borehole. The need expressed at this level is 22 water points in the town.

In N'goutjina municipality, part of the population obtains drinking water from traditional wells.

The said Municipality has 35 boreholes, one of which is in poor condition in N'goutjina for 24,713 inhabitants, or more than 700 inhabitants for one borehole. The expressed need is for 41 modern water points to be achieved.

For the Municipality of M'pèssoba, the drinking water supply is ensured by hydraulic works except the village of Bana each town has a Water Supply Summary. Bana, on the other hand, has a hand pump.

Despite these installations, it is necessary to proceed quickly to the drilling of 15 additional boreholes in the said Municipality which also suffers from the insufficiency of pastoral water points.

In Nafanga, as in other Municipalities, part of the population obtains its supplies from traditional wells.

For a population of 12,089 inhabitants, there are 25 boreholes which are not all in good condition. Here we have one (1) borehole for more than 400 inhabitants.

The Municipality of Sincina has two (02) summary water supply points, 25 boreholes equipped with human-powered pumps, 01 large-diameter wells. It is populated by 26,182 inhabitants.

In Sincina, the supply of drinking water to the populations is far from satisfactory, there are more than 500 inhabitants for a borehole.

Regarding the Municipalities of Zangasso (26,800 inhabitants), Kapala (11,400 inhabitants), Koningué (22,155 inhabitants), we could not find reliable data, but one thing is certain, the water supply population drinking water is poorly assured compared to the national standard which is 400 inhabitants per modern water point. 
Water point management committees exist, but are generally not functional. These committees are only functional in the early days of the construction of hydraulic works. The problem of financial resources is at the root of this dysfunction.

These (Photo 3) illustrate the hydraulic structures that some residents of the municipalities of Zangasso and Mièna use to obtain drinking water. It is a water tower operated by solar energy. However, it should be emphasized that certain villages and hamlets in these Municipalities obtain their supplies from traditional wells and human-powered pumps. Hydraulic works which must begin to make way for modern installations such as summary water supplies from solar energy.

These (Photo 4) illustrate the hydraulic structures that some residents of the
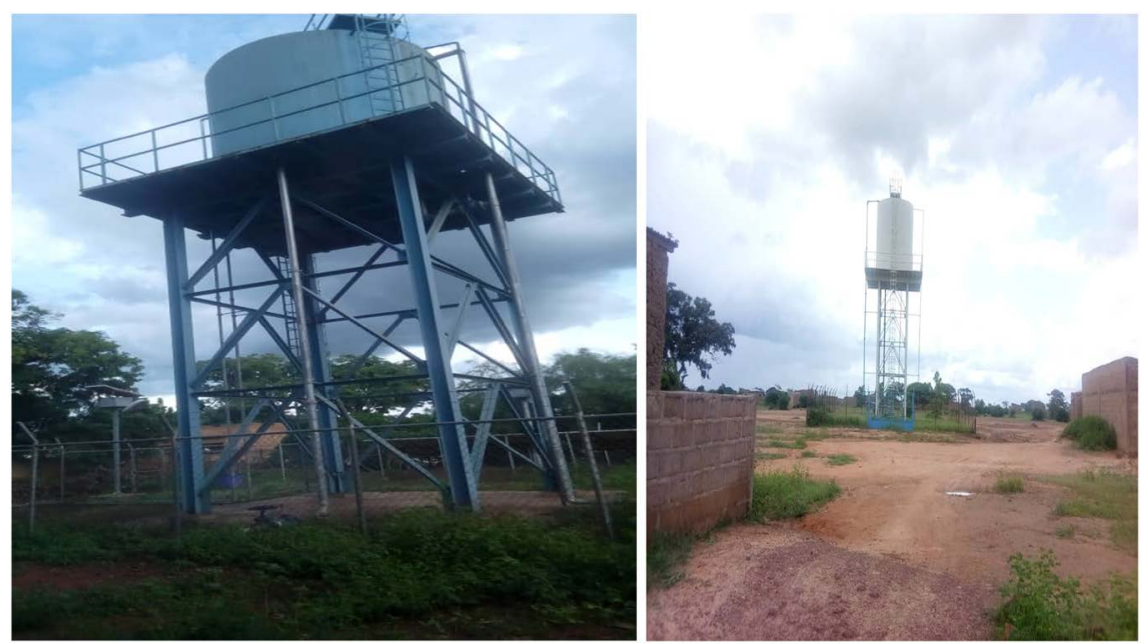

Source: personal photo April 30, 2019 at 11:15 a.m.

Photo 3. Water tower in Zangasso and Mièna.
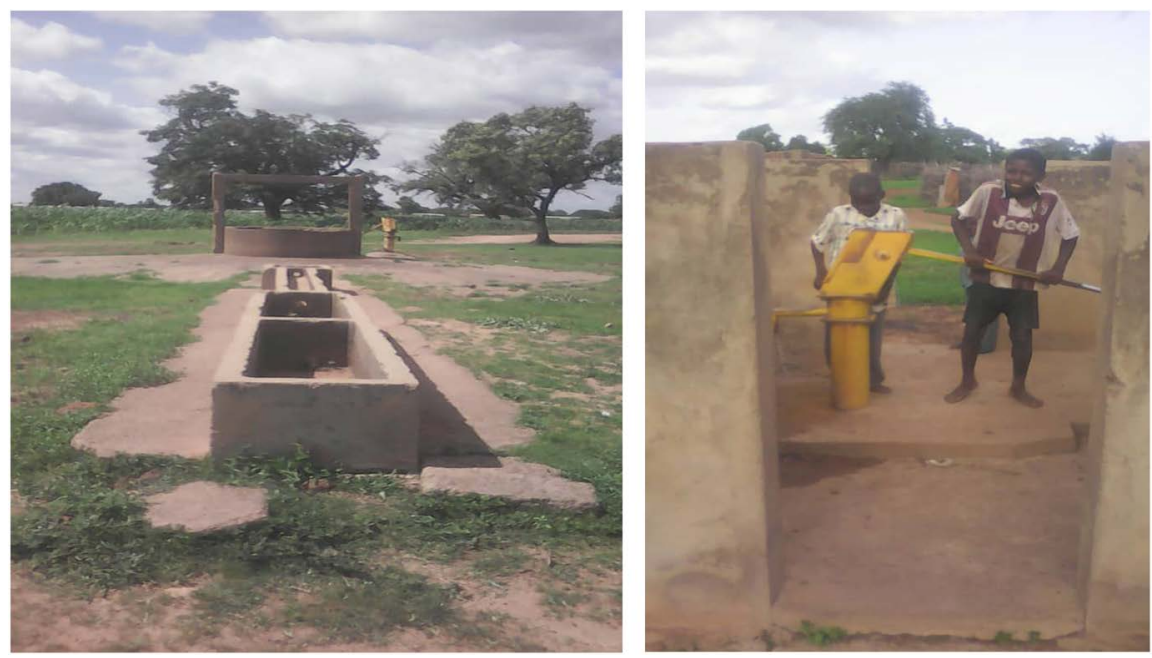

Source: personal photo April 30, 2019 at 11:30 a.m.

Photo 4. Large-diameter well and human-powered pump in the Municipality of Fagui and Tempéla. 
Municipalities of Fagui and Tempéla use to obtain drinking water. It is a large diameter well and a hand pump. These hydraulic works must begin to make way for modern installations such as basic water supplies from solar energy.

\subsubsection{Access to Electricity}

In terms of access to energy, the least we can say is that the city of Koutiala and part of the village of Sincina benefit from an electricity network that does not cover all the needs of the population. in electricity. Many households in these two localities do not have access to electricity. This despite the supply of the municipality of Koutiala by the interconnected network (RI), a component of the interconnection project of the electricity transmission networks of ECOWAS member states, in particular Mali-Côte d'Ivoire (Koutiala Communal Councils, 2017-2018).

In addition, the Circle is covered by the "Yélen Koura" project (solar energy production). However, the high cost of the units did not allow massive access of the populations to this source of energy. Thus, firewood and individual solar panel installations remain the only alternatives for the vast majority of populations (especially rural) (Koutiala Communal Councils, 2017-2018).

These (Photo 5) illustrate the disparity that exists between the urban center of Koutiala and the village of Sorobasso (Rural Municipality of Sorobasso) in terms of access to electricity where low-capacity solar panels are used by residents for lighting.

\subsubsection{Access to Means of Transport and Communication}

According to the Local Planning Scheme, the Cercle's road network is $760 \mathrm{~km}$ long (322 km of asphalted roads in fair condition, $308 \mathrm{~km}$ of dirt roads, $130 \mathrm{~km}$ of rural roads in poor condition) including more than half of it is in poor condition and in most cases difficult to practice during the rainy season. In the Koutiala district, there is no river transport. As for air transport, there is a very little frequented aerodrome $5 \mathrm{~km}$ south-east of the town of Koutiala and located in the rural Municipality of Sincina (Koutiala Communal Councils, 2017-2018).

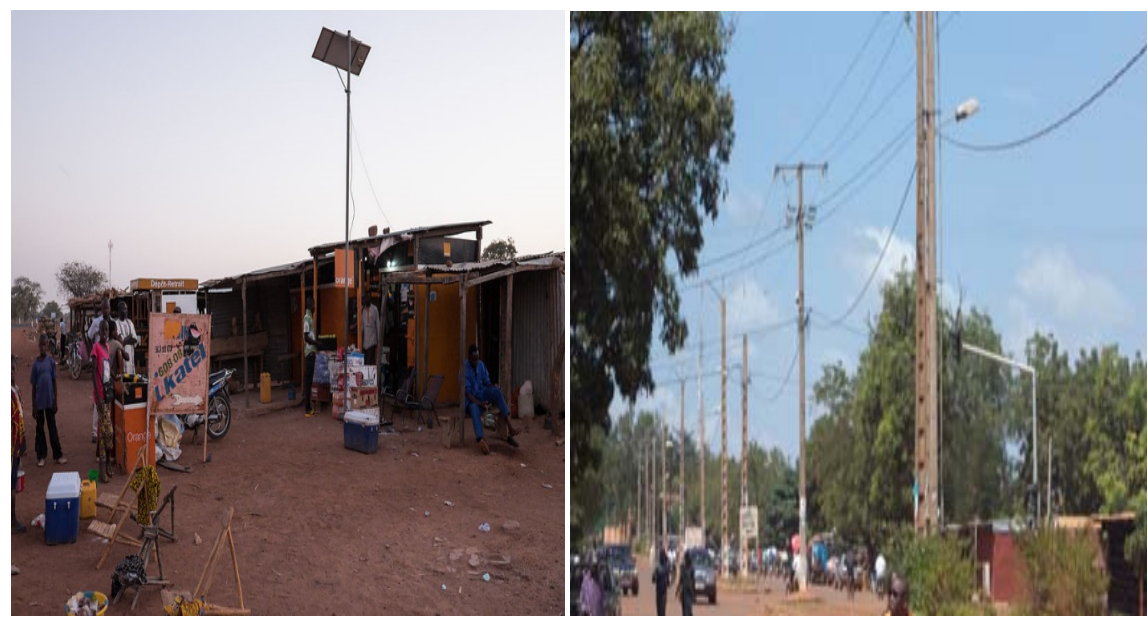

Source: personal photo April 30, 2019 at 11:30 a.m.

Photo 5. Electrification in Sorobasso and Koutiala town. 
The state of the roads does not encourage transporters to make the trips with good vehicles, which consequently increases the accident rate, especially for fairgrounds who, from fair to fair, use dilapidated trucks at the risk of their lives. In each target municipality, there is at least one weekly fair.

The existing postal and telecommunications infrastructure is insufficient, and is sometimes in poor condition and unevenly distributed throughout the territory of the circle. Several villages remain not covered by mobile telephony and the Internet (Koutiala Communal Councils, 2017-2018).

For covered or partially covered villages, the quality of service leaves much to be desired (frequent loss of network, low speed and interference, etc.). The Circle is sufficiently covered by the local radios (Koutiala Circle Council, 2002).

Here we offer you the (Photo 6) of the Zangasso-Ziéna-Kéléni rural track under construction. This track aims to open up this area of agricultural production and in the future facilitate the movement of people and goods in this territory situated between the Circle of Sikasso and the Circle of Koutiala.

\section{Discussion of the Results}

One thing is to register an action, another is to make it happen. Most Municipalities include actions in their PDESCs, but lack the means to implement them.

Thus, the populations are confronted with difficulties of access to health centers and those which exist also suffer from a lack of equipment and personnel, a situation which has persisted for years. If the lack of resources is highlighted by the municipal authorities, it is on the other hand the failure to take into account the territorial aspect in development actions that is underlined by the technical planning services. According to them, most of the projects have been carried out for years in the chief towns.

When it comes to villages, they take a back seat when it comes to investment. All of which partly explains the territorial imbalance observed in most of the municipalities of the Circle of Koutiala in terms of access to basic social infrastructure.

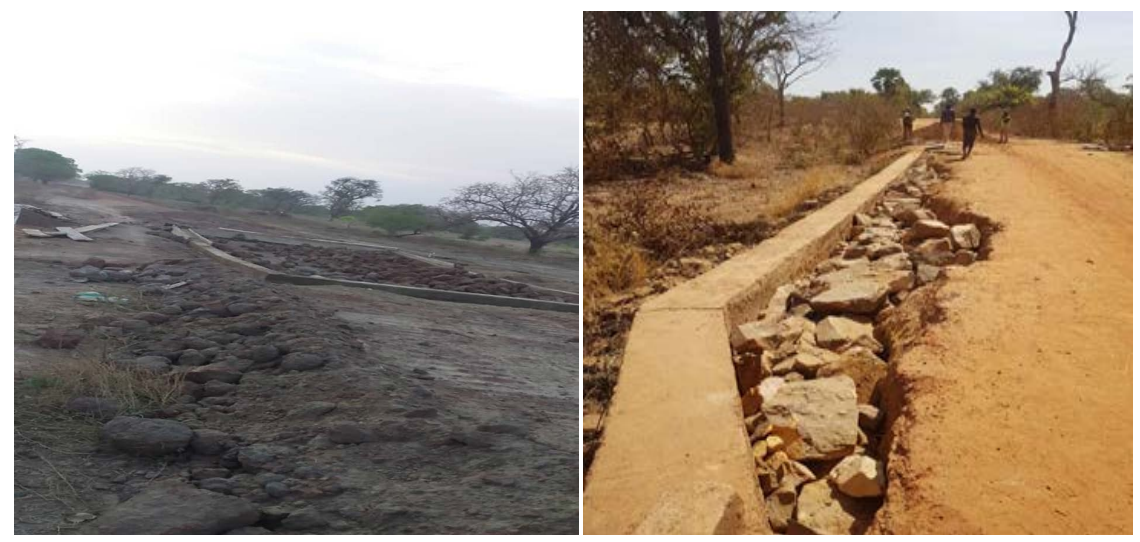

Source: personal photo June 15, 2020 at 9:20 a.m.

Photo 6. Zangasso-Ziéna-Kéléni rural track under construction. 
Lack of awareness of the advantages of spatializing development actions also explains the concentration of investments in a single locality in the municipality, or even the Circle where the town of Koutiala benefits from more investments than the other localities of the Circle.

The interventions outside the programs of technical and financial partners are also factors that create territorial imbalances in terms of investment in the Circle.

Many development partners act in isolation and without taking into account the priorities set out in planning documents. In general, the policies applied in Mali have not yet resulted in balanced and sustainable development.

The observation is a high concentration of investments and of the population of the circle, even of the country in areas with high natural potential. Thus, in our country, the Ségou-Sikasso-Bamako triangle records most of the public investments.

This situation is the result of the combination of difficulties and inadequacies in the application of spatial planning documents (predominance of the sectoral planning approach, gap between demographic change and the preparation of urban planning documents, weak level of interconnection between urban poles and their rural hinterland, little consideration of spatial issues in public development policies, etc.).

Nevertheless, efforts have been made by the authorities towards understanding the issues and territorial challenges and reducing socioeconomic disparities in the circle, and even in the country.

Planning at the local and municipal level, and even at the national level, is specifically confronted with several weaknesses. The gap is growing between the plans and the actual economic decision-making process of communities, even the state, making planning tools mere documents left in drawers.

It has become a mere formal exercise to serve as an instrument for mobilizing resources that are used for other purposes.

\section{Conclusion}

The inconsistency between the planning tools and the non-capitalization of the orientations of the Regional Land Use Planning Scheme of Sikasso, the Local Land Development Scheme of the Cercle de Koutiala, the Master Planning and Urban Planning of the City of Koutiala and its surroundings through the development programs of the said circle, are all elements which confirm that the development actions are not carried out according to the orientations of the spatial planning tools. To these must be added the isolation of the territories, the poor coverage of the territories in basic social services, the insufficiency and/or absence of infrastructure and structuring equipment in several municipalities, the weight of influences political, social and religious, the pauperization of the territories, the influx of populations to certain localities of the Circle, in particular the city of Koutiala. Planning tools no longer mobilize the necessary resources for financing the projects selected and the participatory approach in the development and implementation of planning tools is very often limited to benefi- 
ciary consultation sessions. The balanced development of the territories is not guaranteed. Access to basic social services remains a major concern in most local authorities.

To do this, it is necessary to create a regional development fund, provide local authorities with planning tools and ensure their application.

In terms of limits, I think the multidimensional approach has sometimes turned into a plethora of information, and that the multiplication of angles of attack has worked at the expense of clarity.

Finally, the unavailability of data, the diversity of sources and the multiplicity of territorial actors have often led me to be too broad and less precise in my remarks.

\section{Conflicts of Interest}

The author declares no conflicts of interest regarding the publication of this paper.

\section{References}

Koutiala Communal Councils (2017-2018). Development Programs for the Municipalities of the Koutiala Circle. Koutiala: Offices of Municipalities of Koutiala.

Koutiala Circle Council (2002). Local Development Plan of the Circle of Koutiala. Koutiala: General Secretariat of Koutiala Circle Council.

National Directorate of Population (2018). Demographic Projection of Mali. Bamako: Office of DNP.

National Technical Assessment Committee of Urban Master Plans and Sectorial Town Plans (2018). Koutiala SDAU Assessment Report. Bamako: Secretariat of the Committee.

National Institute of Statistics (2009). Theme 2 State and Structure of the Population. https://www.instat-mali.org/fr 